\title{
BMJ Open Drug treatment of macular oedema secondary to central retinal vein occlusion: a network meta-analysis
}

\author{
John A Ford, ${ }^{1}$ Deepson Shyangdan, ${ }^{2}$ Olalekan A Uthman, ${ }^{2}$ Noemi Lois, ${ }^{3}$ \\ Norman Waugh ${ }^{2}$
}

To cite: Ford JA, Shyangdan D, Uthman $O A$, et al. Drug treatment of macular oedema secondary to central retinal vein occlusion: a network metaanalysis. BMJ Open 2014;4: e005292. doi:10.1136/ bmjopen-2014-005292

- Prepublication history and additional material is available. To view please visit the journal (http://dx.doi.org/ 10.1136/bmjopen-2014005292).

Received 20 March 2014 Revised 27 June 2014 Accepted 30 June 2014
CrossMark

\footnotetext{
${ }^{1}$ Department of Population Health and Primary Care, University of East Anglia, Norwich, UK

${ }^{2}$ Warwick Evidence, University of Warwick, Coventry, UK

${ }^{3}$ Centre for Vision and Vascular Science, Queen's University, Belfast, UK
}

Correspondence to Dr John Ford; John.ford@uea.ac.uk

\section{ABSTRACT}

Objective: To indirectly compare aflibercept, bevacizumab, dexamethasone, ranibizumab and triamcinolone for treatment of macular oedema secondary to central retinal vein occlusion using a network meta-analysis (NMA).

Design: NMA.

Data sources: The following databases were searched from January 2005 to March 2013: MEDLINE, MEDLINE In-process, EMBASE; CDSR, DARE, HTA, NHSEED, CENTRAL; Science Citation Index and Conference Proceedings Citation Index-Science.

Eligibility criteria for selecting studies: Only randomised controlled trials assessing patients with macular oedema secondary to central retinal vein occlusion were included. Studies had to report either proportions of patients gaining $\geq 3$ lines, losing $\geq 3$ lines, or the mean change in best corrected visual acuity. Two authors screened titles and abstracts, extracted data and undertook risk of bias assessment. Bayesian NMA was used to compare the different interventions.

Results: Seven studies, assessing five drugs, were judged to be sufficiently comparable for inclusion in the NMA. For the proportions of patients gaining $\geq 3$ lines, triamcinolone $4 \mathrm{mg}$, ranibizumab $0.5 \mathrm{mg}$, bevacizumab $1.25 \mathrm{mg}$ and aflibercept $2 \mathrm{mg}$ had a higher probability of being more effective than sham and dexamethasone. A smaller proportion of patients treated with triamcinolone $4 \mathrm{mg}$, ranibizumab $0.5 \mathrm{mg}$ or aflibercept $2 \mathrm{mg}$ lost $\geq 3$ lines of vision compared to those treated with sham. Patients treated with triamcinolone $4 \mathrm{mg}$, ranibizumab $0.5 \mathrm{mg}$, bevacizumab $1.25 \mathrm{mg}$ and aflibercept $2 \mathrm{mg}$ had a higher probability of improvement in the mean best corrected visual acuity compared to those treated with sham injections.

Conclusions: We found no evidence of differences between ranibizumab, aflibercept, bevacizumab and triamcinolone for improving vision. The antivascular endothelial growth factors (VEGFs) are likely to be favoured because they are not associated with steroidinduced cataract formation. Aflibercept may be preferred by clinicians because it might require fewer injections.

Systematic review registration: Not registered.

\section{Strengths and limitations of this study}

- Important topic area, with significant policy implications.

- Robust method used to identify studies.

- Network meta-analyses are based on a number of assumptions.

- Network meta-analysis is the best method to compare interventions in the absence of head-tohead trials.

\section{INTRODUCTION}

Central retinal vein occlusion (CRVO) dramatically reduces an individual's functioning and quality of life. ${ }^{1}$ It is estimated that the 15-year cumulative incidence of CRVO is $0.5 \% .^{2}$ Visual loss is caused by thrombosis of the central retinal vein which leads to a rise in venous pressure and an increase in vascular endothelial growth factor (VEGF), consequently causing an increase in vascular permeability. Macular oedema subsequently ensues with varying degrees of ischaemia and neovascularisation. Although CRVO is generally classified as ischaemic or non-ischaemic, ischaemia should be regarded as a spectrum. ${ }^{3}$ Cases with ischaemia carry a considerably worse prognosis as, in around one-third of them, neovascular glaucoma, the most devastating complication of CRVO, may develop. ${ }^{4}$

CRVO is more common in older people with risk factors such as diabetes, hypertension or hyperlipidaemia, but can occur in young people with inflammatory disorders. Hayreh et al, in a 27-year cohort study, found that only $13 \%$ of people with CRVO were under 45 years of age. ${ }^{3}$ In $95 \%$ of cases, CRVO affects only one eye. ${ }^{3}$ However, visual loss in this already comorbid patient group significantly compounds their already impaired functioning and quality of life. Patients can lose confidence, struggle with 
daily activities and become increasingly dependent on friends and family. ${ }^{1}$

For many years, laser photocoagulation was the only effective therapeutic strategy that could be used in the management of patients with CRVO. It was only useful for reducing the risk of neovascular glaucoma, but not effective for the treatment of macular oedema in CRVO. ${ }^{5}$ Over the past decade, a number of drugs to treat macular oedema have been introduced, including the steroids, triamcinolone and dexamethasone, and the anti-VEGFs, ranibizumab, bevacizumab, pegaptanib and aflibercept. Dexamethasone, ranibizumab and aflibercept have been assessed in large commercially funded trials. $^{6-13}$ Bevacizumab was originally developed as an anticancer drug and has been found to be effective in treating macular oedema secondary to age-related macular degeneration, ${ }^{14}$ diabetic macular oedema, ${ }^{15}$ branch retinal vein occlusion ${ }^{16}$ and CRVO ${ }^{17}$ Like triamcinolone, bevacizumab is used off license in the eye. Ranibizumab is derived from the same parent molecule of the bevacizumab monoclonal antibody and was developed and commercially marketed specifically for use in the eye.

In the UK, the National Institute of Health and Care Excellence (NICE) has recommended the use of dexamethasone, ranibizumab and aflibercept for the treatment of macular oedema secondary to CRVO in separate appraisals. ${ }^{18-20}$ Therefore clinicians have three NICE-recommended treatments for CRVO without head-to-head trials or clear guidance in which one may be best for their patients. On this basis, the aim of this study was to indirectly compare, in a network meta-analysis (NMA), the clinical effectiveness of aflibercept, ranibizumab, bevacizumab, dexamethasone and triamcinolone for the treatment of macular oedema secondary to CRVO.

\section{METHODS}

\section{Information sources and search strategy}

To identify suitable studies, initially for a systematic review of treatment of macular oedema after CRVO (submitted for publication), the following databases were searched from January 2005 to March 2013: MEDLINE, MEDLINE In-process, EMBASE (all via OVID); CDSR, DARE, HTA, NHSEED, CENTRAL (all via The Cochrane Library); Science Citation Index and Conference Proceedings Citation Index-Science (via Web of Knowledge). The MEDLINE search strategy is shown in the online supplementary appendix 1. This search strategy was modified for other databases. In addition to the bibliographic database searching, supplementary searches were undertaken to look for recent and unpublished studies in the WHO International Clinical Trials Registry Platform and ophthalmology conference websites (American Academy of Ophthalmology, Association for Research in Vision and Ophthalmology from 2010 to 2012).

\section{Study selection}

Only randomised controlled trials which included patients with macular oedema secondary to CRVO were included. It was acceptable for a study to include branch retinal vein occlusion and CRVO provided that the CRVO group was reported separately. The following drugs were included: dexamethasone, triamcinolone, ranibizumab, bevacizumab and aflibercept. Pegaptanib was not included because it is not used routinely in clinical practice. Only doses that are used in clinical practice were included. Studies had to report at least one of the following outcomes: proportions of patients gaining $\geq 3$ lines from baseline to 6 months, proportions of patients losing $\geq 3$ lines from baseline to 6 months and the mean change in best corrected visual acuity (BCVA) from baseline to 6 months.

\section{Risk of bias assessment}

The Cochrane Collaboration's tool was used for assessing risk of bias. ${ }^{21}$ The trials were graded (unclear, high or low risk of bias) based on: (1) sequence generation, (2) allocation concealment, (3) blinding of outcome assessor, (4) incomplete outcome data and (5) selective outcome reporting.

\section{Study selection and data abstraction}

Two authors independently assessed the eligibility and methodological quality of the studies identified during the literature search. Two authors extracted and compared the data. For each study identified that met the selection criteria, details on study design, study population characteristics, intervention, outcome measures and study quality were extracted. Discrepancies were resolved by consensus through discussion. Studies were assessed for comparability based on the populations included, trial arms, outcome measures and duration of follow-up. Common comparators were identified from the trials and a network diagram was created.

\section{Summary measures}

The primary measures of treatment effects were relative risk (RR) for the proportions of patients gaining $\geq 3$ lines of vision, proportions of patients losing $\geq 3$ lines of vision and the weighted mean difference (WMD) for mean change BCVA. We used the following methods to calculate SDs when incompletely reported: (1) contact with the corresponding author or (2) estimation of the $\mathrm{SD}$ on the basis of the sample size, median and range as suggested by Hozo et $a l^{22}$ or on the basis of the sample size and $\mathrm{p}$ value.

In one trial (SCORE), ${ }^{23-36}$ 6-month data were not available because patients were followed up every 4 months. For the dichotomous outcomes, that is, proportions of patients gaining and losing $\geq 3$ lines, we averaged 4 and 8-month data to get the 6 months follow up data. For the third outcome, that is, mean change BCVA, again data from two time-points were used. The 
weighted mean and SDs for each treatment arm were calculated using the mean and SDs of two time-points.

\section{Data synthesis and model implementation}

Bayesian NMA $^{37} 38$ was used to compare the different interventions. NMA is a generalisation of meta-analysis methods because it allows comparisons of agents not addressed within individual primary trials. Bayesian statistical inference provides probability distributions for treatment effect parameters (RR and WMD), with 95\% credible intervals $(95 \% \mathrm{CrI})$, rather than $95 \%$ CIs $(95 \% \mathrm{CI})$. A 95\% CrI can be interpreted as there being a $95 \%$ probability that the parameter takes a value in the specified range. 3738

All analyses were conducted using a Bayesian Markov Chain Monte Carlo (MCMC) method and fitted in the freely available Bayesian software, WinBUGS V.1.4.3. ${ }^{39}$ Two Markov chains were run simultaneously using different initial values. Convergence to a stable solution was checked by viewing plots of the sampled simulations and using the Brooks-Gelman-Rubin diagnostic tool. ${ }^{40}$ Convergence was found to be adequate after running 20000 samples for both chains. These samples were then discarded and a further 70000 sampled simulation was then run, on which the results were based. We also calculated the probability of treatment being the most effective (first best), the second best, the third best and so on, and presented the results graphically with rankograms. ${ }^{41}$

Like standard meta-analysis comparison, an NMA can be either a fixed-effect or a random-effect model. We used the Bayesian Deviation Information Criterion (DIC) to compare fixed-effect and random-effect models. The most appropriate NMA model can be identified as the one with the lowest DIC. The DIC measures the fit of the model while penalising it for the number of effective parameters. The fixed-effect model was chosen because of the small number of trials available for each comparison, and difficulty in estimating between studies variance, if random-effect model, was implemented, and the difference in DIC was less than 5.

\section{RESULTS}

\section{Study selection and characteristics}

The literature search identified 945 articles, as shown in figure 1 . Seven studies were judged to be sufficiently comparable to be included in the NMA. Tables 1 and 2

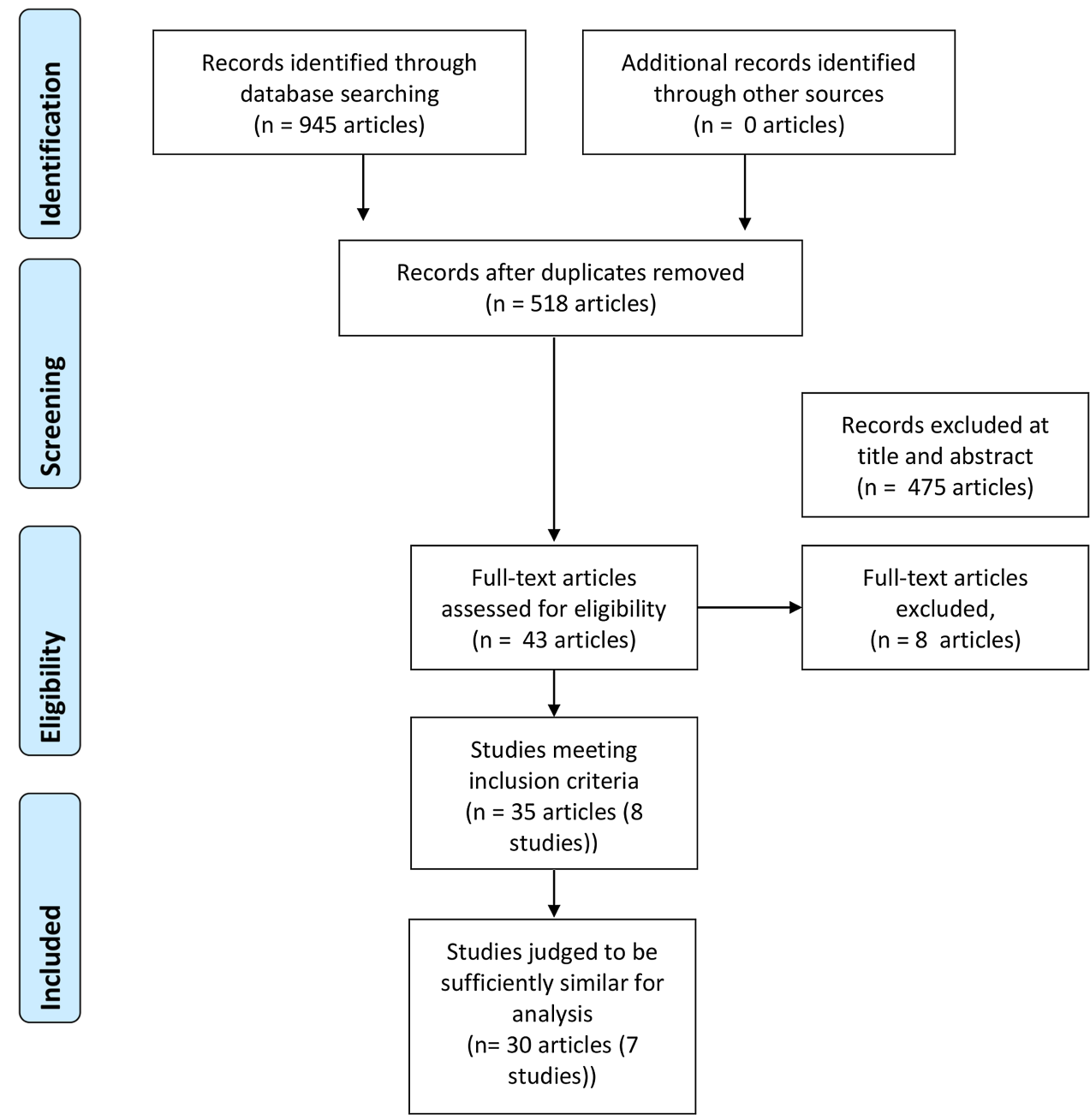

Figure 1 Study selection flow diagram. 
Table 1 Baseline characteristics and results of all included studies

\begin{tabular}{|c|c|c|}
\hline Study & Participants & Intervention/outcomes \\
\hline \multicolumn{3}{|l|}{ DEXAMETHASONE } \\
\hline $\begin{array}{l}\text { GENEVA } 2010^{6-8} \\
\text { International }\end{array}$ & $\begin{array}{l}N \text { : CRVO- } 437 \text { eyes of } 437 \text { patients } \\
\text { randomised; } 94 \% \text { follow-up at } 6 \text { months }\end{array}$ & $\begin{array}{l}\text { 1. Dexamethasone } 0.7 \mathrm{mg}(n=136) \text { Single } \\
\text { dose }\end{array}$ \\
\hline $\begin{array}{l}\text { Setting: multicentre ( } 167 \text { centres in } \\
24 \text { countries, so a mean of } 2.6\end{array}$ & $\begin{array}{l}\text { Participants: adults with visual acuity } \\
\text { reduced because of macular oedema }\end{array}$ & $\begin{array}{l}\text { 2. Dexamethasone } 0.35 \mathrm{mg}(n=154) \\
\text { Single dose }\end{array}$ \\
\hline patients per centre) & due to CRVO or BRVO & 3. Sham $(n=147)$ Single dose-a \\
\hline $\begin{array}{l}\text { Design: } 2 \text { identical double-blind, } \\
\text { sham-controlled RCTs, phase } 3\end{array}$ & & $\begin{array}{l}\text { needleless applicator was placed } \\
\text { against the conjunctiva to simulate the }\end{array}$ \\
\hline Follow-up: primary endpoint for the & & placement of study medication. \\
\hline masked trial: 6 months; primary & & Primary end point: gain of $\geq 15$ ETDRS \\
\hline $\begin{array}{l}\text { endpoint for the open-label extension: } \\
12 \text { months }\end{array}$ & & letters; for the open-label extension: safety \\
\hline \multicolumn{3}{|l|}{ TRIAMCINOLONE } \\
\hline SCORE $2009^{23-36}$ & $N: 271$ eyes of 271 patients & 1. Triamcinolone $1 \mathrm{mg}(\mathrm{n}=92)$ Every \\
\hline USA & randomised; 83\% (observation) and & 4 months depending on retreatment \\
\hline Setting: multicentre & $90 \%$ (triamcinolone) completed & regimen (average 2.2 injections at \\
\hline Design: RCT & 12 months & 12 months) \\
\hline Follow-up: primary end point & Participants: centre-involved macular & 2. Triamcinolone $4 \mathrm{mg}(n=91)$ Every \\
\hline 12 months, FU planned up to & oedema secondary to CRVO & 4 months depending on retreatment \\
\hline 36 months & & $\begin{array}{l}\text { regimen (average } 2.0 \text { injections at } \\
12 \text { months) (The form of triamcinolone } \\
\text { used was Trivaris, no longer available. } \\
\text { It was made by the manufacturer of } \\
\text { Ozurdex (Allergan)) }\end{array}$ \\
\hline & & 3. Observation $(n=88)$ \\
\hline & & $\begin{array}{l}\text { Primary end point: gain of } \geq 15 \text { ETDRS } \\
\text { letters }\end{array}$ \\
\hline
\end{tabular}

\section{COPERNICUS $2012^{1213}$ \\ International}

Setting: multicentre, 70 sites in North and South America, India and Israel.

Mean 2.7 patients per centre

Design: double-blind, sham-controlled

RCT, phase 3

Follow-up: primary end point

24 weeks, FU 2 years

GALILEO $2012^{11}$

International

Setting: multicentre, 10 countries in

Europe and Asia; 63 centres in total

Design: double-blind, sham-controlled

$\mathrm{RCT}$, phase 3

Follow-up: primary end point

24 weeks, FU up to 12 months,

planned up to 76 weeks

\section{RANIBIZUMAB}

CRUISE $2010^{9} 10$

USA

Setting: multicentre

Design: double-blind, sham-controlled RCT, phase 3

Follow-up: primary end point

6 months, FU up to 12 months
$N: 189$ eyes of 189 patients randomised; 95.7\% (aflibercept) and $81.1 \%$ (sham) completed 24 weeks; 93\% (aflibercept) and 77\% (sham) completed 52 weeks

Participants: adult patients with centre-involved CRVO for a maximum of 9 months

$N: 177$ eyes of 177 patients randomised; 90.6\% (aflibercept) and $78.9 \%$ (sham) completed 24 weeks Participants: treatment-naïve patients with centre-involved CRVO for a maximum of 9 months

N: 392 eyes of 392 patients randomised; $97.7 \%$ (ranibizumab $0.3 \mathrm{mg}$ ), $91.5 \%$ (ranibizumab $0.5 \mathrm{mg}$ ) and $88.5 \%$ (sham) completed 6 months Participants: patients with foveal centre-involved macular oedema secondary to CRVO diagnosed within 12 months
1. Aflibercept 2 mg ( $n=114)$ Every 4 weeks for 6 months (average number not available)

2. Sham ( $n=73$ ) Every 4 weeks for 6 months (average number not available) (empty syringe without needle pressed to conjunctival surface) Primary end point: gain of $\geq 15$ ETDRS letters

1. Aflibercept 2 mg ( $n=103)$ Every 4 weeks for 6 months (average number not available)

2. Sham $(n=71)$ Every 4 weeks for 6 months (average number not available) (empty syringe without needle pressed to conjunctival surface)

Primary end point: gain of $\geq 15$ ETDRS letters

1. Ranibizumab $0.3 \mathrm{mg}(n=132)$ Every 4 weeks for 6 months (average number not available)

2. Ranibizumab $0.5 \mathrm{mg}(n=130)$ Every 4 weeks for 6 months (average number not available)

3. Sham $(n=130)$ Every 4 weeks for 6 months (average number not available) (empty syringe without needle pressed to the injection site)

Primary end point: mean change from baseline BCVA 
Table 1 Continued

\begin{tabular}{|c|c|c|}
\hline Study & Participants & Intervention/outcomes \\
\hline $\begin{array}{l}\text { BEVACIZUMAB } \\
\text { EPSTEIN } 2012^{42-44} \\
\text { Sweden } \\
\text { Setting: Single centre; St. Eriks Eye } \\
\text { Hospital Stockholm } \\
\text { Design: sham-injection controlled, } \\
\text { double maskedRCT } \\
\text { Follow-up: primary endpoint } \\
6 \text { months; open label extension up to } \\
12 \text { months }\end{array}$ & $\begin{array}{l}N: 60 \text { eyes of } 60 \text { patients randomised; } \\
93 \% \text { completed open label extension } \\
\text { Participants: patients with CRVO of } \\
\leq 6 \text { months }\end{array}$ & $\begin{array}{l}\text { 1. Bevacizumab } 1.25 \mathrm{mg} \text { ( } n=30 \text { ) Every } \\
6 \text { weeks for } 6 \text { months (average number } \\
\text { not available) } \\
\text { 2. Sham ( } n=30 \text { ) Every } 6 \text { weeks for } \\
6 \text { months (averege number not } \\
\text { available) (syringe without needle } \\
\text { pressed to the globe) } \\
\text { Primary end point: gain of } \geq 15 \text { ETDRS } \\
\text { letters }\end{array}$ \\
\hline
\end{tabular}

present the characteristics and results of the included trials. Two studies ${ }^{11-13}$ compared aflibercept $2 \mathrm{mg}$ against sham; two identical studies ${ }^{6-8}$ compared dexamethasone $0.7 \mathrm{mg}$ (Ozurdex) against sham; one study ${ }^{9}{ }^{10}$ compared ranibizumab $0.5 \mathrm{mg}$ against sham; one study ${ }^{42-44}$ compared bevacizumab $1.25 \mathrm{mg}$ against sham and, finally, one study ${ }^{23-36}$ compared triamcinolone $4 \mathrm{mg}$ against observation. Sham or observation was used as the common comparator. The number of included participants varied from $60^{42-44}$ to $437 .^{6-8}$ Most studies required patients to be treatment naïve and have macular oedema with retinal thickness measuring at least 250 or $300 \mu \mathrm{m}$ on optical coherence tomography. Sham injection was undertaken by placing a needleless syringe on the eye. All studies, except for Epstein $e t a l^{42-44}$ were multi-centre, international studies. Most studies had an extension phase after the primary outcome, but this was not included in the NMA.

The sufficiently comparable studies were combined into a network analysis based on a common comparator. The network for the proportions of patients gaining $\geq 3$ lines is shown in figure 2. This network is the same for the other two outcomes, but without dexamethasone, because the trial did not report these outcomes.

\section{Risk of bias of included trials}

Risk of bias is shown in table 3. Included studies were generally of high quality, with all studies being judged to be of low or unclear bias for all criteria. The noncommercially funded bevacizumab trial had fewer patients and, inevitably, results had wider CIs. ${ }^{42-44}$ In no study does it appear that patients were asked at the end of the trial which arm they thought they had been assigned. It is unclear how many could distinguish injections (intervention arm) from punctureless pressure (sham arm).

\section{Effects of interventions on proportions of patients gaining $\geq 3$ lines}

Figure 3 displays a forest plot of the risk ratio and $95 \%$ CrI in proportions of patients gaining $\geq 3$ lines for all the possible pairwise comparisons. In terms of proportions of patients gaining $\geq 3$ lines, triamcinolone $4 \mathrm{mg}$, ranibizumab $0.5 \mathrm{mg}$, bevacizumab $1.25 \mathrm{mg}$ and aflibercept $2 \mathrm{mg}$ had a higher probability of being more effective than a sham and dexamethasone (figure 4). There was no difference in the proportions of patients gaining $\geq 3$ lines between triamcinolone $4 \mathrm{mg}$, ranibizumab $0.5 \mathrm{mg}$, bevacizumab $1.25 \mathrm{mg}$ and aflibercept $2 \mathrm{mg}$.

\section{Effects of interventions on proportions of patients losing $\geq 3$ lines}

Figure 5 displays forest plot of the risk ratio and $95 \%$ CrI of proportions of patients losing $\geq 3$ lines for all the possible pairwise comparisons. A smaller proportion of patients treated with triamcinolone $4 \mathrm{mg}$, ranibizumab $0.5 \mathrm{mg}$ or aflibercept $2 \mathrm{mg}$ lost $\geq 3$ lines of vision than those treated with sham. There was no difference in the proportions of patients losing $\geq 3$ lines between triamcinolone $4 \mathrm{mg}$, ranibizumab $0.5 \mathrm{mg}$, bevacizumab $1.25 \mathrm{mg}$ and aflibercept $2 \mathrm{mg}$. Figure 6 shows ranking for efficacy in terms of proportions of patients losing $\geq 3$ lines.

\section{Effects of interventions on mean change in BCVA}

Figure 7 displays a forest plot of the mean changes and 95\% CrIs of improvement in BCVA for all the possible pairwise comparisons. Patients treated with triamcinolone $4 \mathrm{mg}$, ranibizumab $0.5 \mathrm{mg}$, bevacizumab $1.25 \mathrm{mg}$ or aflibercept $2 \mathrm{mg}$ had a higher probability of improvement in BCVA compared to those treated with sham injections. Patients treated with aflibercept $2 \mathrm{mg}$ had a higher probability of improvement in BCVA compared with those treated with triamcinolone $4 \mathrm{mg}$ (figure 8). There was no difference in the mean change in BCVA from baseline between patients treated with ranibizumab $0.5 \mathrm{mg}$, bevacizumab $1.25 \mathrm{mg}$ and aflibercept $2 \mathrm{mg}$.

\section{DISCUSSION}

\section{Statement of principal findings}

Our results show no evidence of a difference in effectiveness between aflibercept, ranibizumab and triamcinolone. Bevacizumab was similar to these drugs in terms of 
Table 2 Baseline characteristics and results of included trials

\begin{tabular}{|c|c|c|c|c|c|}
\hline Copernicus $^{1213}$ & Galileo $^{11}$ & Cruise $^{910}$ & Geneva $^{6-8}$ & Epstein et $a I^{42-44}$ & Score $^{23-36}$ \\
\hline \multicolumn{6}{|l|}{ Baseline similarities } \\
\hline \multicolumn{6}{|l|}{ Number $(\%)$ of patients } \\
\hline Aflib 2 mg: 114 & Aflib 2 mg: 103 & Rani 0.5 mg: 130 & $\begin{array}{l}\text { Dexa } 0.7 \mathrm{mg}: \\
136\end{array}$ & Beva 1.25 mg: 30 & Triam 4 mg: 91 \\
\hline Sham: 73 & Sham: 68 & Sham: 130 & Sham: 147 & Sham: 30 & Obser: 88 \\
\hline \multicolumn{6}{|l|}{ Age (years) } \\
\hline Aflib 2 mg: 65.5 SD 13.6 & $\begin{array}{l}\text { Aflib } 2 \text { mg: } 59.9 \text { SD } \\
12.4\end{array}$ & $\begin{array}{l}\text { Rani } 0.5 \mathrm{mg}: 67.6 \\
\text { SD } 12.4\end{array}$ & $\begin{array}{l}\text { Dexa } 0.7 \mathrm{mg}: \\
\text { NR }\end{array}$ & $\begin{array}{l}\text { Beva } 1.25 \mathrm{mg}: 70.6 \\
\text { SD } 12.6\end{array}$ & Triam 4 mg: 67.5 SD 12.0 \\
\hline Sham: 67.5 SD 14.3 & Sham: 63.8 SD 13.3 & $\begin{array}{l}\text { Sham: } 65.4 \text { SD } \\
13.1\end{array}$ & Sham: NR & $\begin{array}{l}\text { Sham: } 70.4 \text { SD } \\
10.4\end{array}$ & Obser: 69.2 SD 12.8 \\
\hline \multicolumn{6}{|l|}{ BCVA at baseline (SD) } \\
\hline Aflib 2 mg: 50.7 SD 13.90 & $\begin{array}{l}\text { Aflib } 2 \text { mg: } 53.6 \text { SD } \\
15.8\end{array}$ & $\begin{array}{l}\text { Rani } 0.5 \mathrm{mg}: 48.1 \\
\text { SD } 14.6\end{array}$ & $\begin{array}{l}\text { Dexa } 0.7 \mathrm{mg}: \\
\text { NR }\end{array}$ & $\begin{array}{l}\text { Beva } 1.25 \mathrm{mg}: 44.4 \\
\text { SD } 15.3\end{array}$ & Triam 4 mg: 51.0 SD 14.4 \\
\hline Sham: 48.9 SD 14.42 & Sham: 50.9 SD 15.4 & $\begin{array}{l}\text { Sham: } 49.2 \text { SD } \\
14.7\end{array}$ & Sham: NR & $\begin{array}{l}\text { Sham: } 43.6 \mathrm{SD} \\
16.0\end{array}$ & Obser: 52.1 SD 13.1 \\
\hline \multicolumn{6}{|c|}{ Duration of $\mathrm{MO}$ from diagnosis to screening } \\
\hline $\begin{array}{l}\text { Aflib } 2 \text { mg: } 2.73 \text { SD } 3.09 \\
\text { (in months) }\end{array}$ & $\begin{array}{l}\text { Aflib } 2 \text { mg: } 50.9 \text { SD } \\
\text { 15.4) (in days) }\end{array}$ & Rani 0.5 mg: - & $\begin{array}{l}\text { Dexa } 0.7 \mathrm{mg}: \\
\text { NR }\end{array}$ & Beva 1.25 mg: NR & Triam 4 mg: 4.2 SD 3.6 (in months) \\
\hline $\begin{array}{l}\text { Sham: } 1.88 \text { SD } 2.19 \text { (in } \\
\text { months) }\end{array}$ & $\begin{array}{l}\text { Sham: } 87.6 \text { SD } 79.1 \\
\text { (in days) }\end{array}$ & Sham: - & Sham: NR & Sham: NR & Obser: 4.2 SD 3.1 (in months) \\
\hline \multicolumn{6}{|l|}{ Results } \\
\hline \multicolumn{6}{|c|}{ Number (\%) of patients gaining $\geq 15$ letters improvement from baseline to 6 months } \\
\hline Aflib 2 mg: 64 (56.1) & Aflib 2 mg: 62 (60.2) & $\begin{array}{l}\text { Rani } 0.5 \mathrm{mg}: 62 \\
(47.7)\end{array}$ & $\begin{array}{l}\text { Dexa } 0.7 \mathrm{mg}: 25 \\
(18)\end{array}$ & $\begin{array}{l}\text { Beva } 1.25 \mathrm{mg}: 18 \\
(60 \%)\end{array}$ & $\begin{array}{l}\text { Triam } 4 \text { mg: } 18 \text { (19.5\%) (average of } 4 \text { and } \\
8 \text { months) }\end{array}$ \\
\hline Sham: 9 (12.3) & Sham: 15 (22.1) & Sham: 22 (16.9) & Sham: 18 (12) & Sham: $6(20 \%)$ & Obser: 3 (4\%) (average of 4 and 8 months) \\
\hline \multicolumn{6}{|c|}{ Number $(\%)$ of patients losing $\geq 15$ letters of BCVA from baseline to 6 months } \\
\hline Aflib 2 mg: 2 (1.8) & Aflib 2 mg: 8 (7.8) & $\begin{array}{l}\text { Rani } 0.5 \mathrm{mg}: 2 \\
(1.5)\end{array}$ & $\begin{array}{l}\text { Dexa } 0.7 \mathrm{mg}: \\
\text { NR }\end{array}$ & $\begin{array}{l}\text { Beva } 1.25 \mathrm{mg}: 2 \\
(6.7 \%)\end{array}$ & $\begin{array}{l}\text { Triam } 4 \text { mg: } 19 \text { (20.5\%) (average of } 4 \text { and } 8 \\
\text { months) }\end{array}$ \\
\hline Sham: $20(27.4)$ & Sham: 15 (22.1) & Sham: 20 (15.4) & Sham: NR & Sham: 7 (23.3\%) & Obser: 31 (35.5\%) (average of 4 and 8 months) \\
\hline \multicolumn{6}{|c|}{ Mean change (SD) from baseline in BCVA } \\
\hline Aflib 2 mg: 17.3 (12.8) & Aflib 2 mg: 18.0 (12.2) & $\begin{array}{l}\text { Rani } 0.5 \mathrm{mg}: 14.9 \\
(13.2)\end{array}$ & $\begin{array}{l}\text { Dexa } 0.7 \mathrm{mg}: 0.1 \\
\text { (NR) }\end{array}$ & $\begin{array}{l}\text { Beva } 1.25 \mathrm{mg}: 14.1 \\
\text { SD } 18.7\end{array}$ & $\begin{array}{l}\text { Triam } 4 \text { mg: }-0.15 \text { SD } 20.67(n=85) \text { (weight } \\
\text { mean and SD of } 4 \text { and } 8 \text { months) }\end{array}$ \\
\hline Sham: $-4(18)$ & Sham: 3.3 (14.1) & Sham: 0.8 (16.2) & $\begin{array}{l}\text { Sham: }-1.8 \\
\text { (NR) }\end{array}$ & $\begin{array}{l}\text { Sham: }-2.0 \text { SD } \\
20.5\end{array}$ & $\begin{array}{l}\text { Obser: }-9.66 \text { SD } 18.04(n=75) \text { (weighted mean } \\
\text { and SD of } 4 \text { and } 8 \text { months) }\end{array}$ \\
\hline
\end{tabular}

Aflib, aflibercept; BCVA, best corrected visual acuity; Dexa, dexamethasone; NR, not reported; Obser, observation; Rani, ranibizumab; Triam, triamcinolone. 


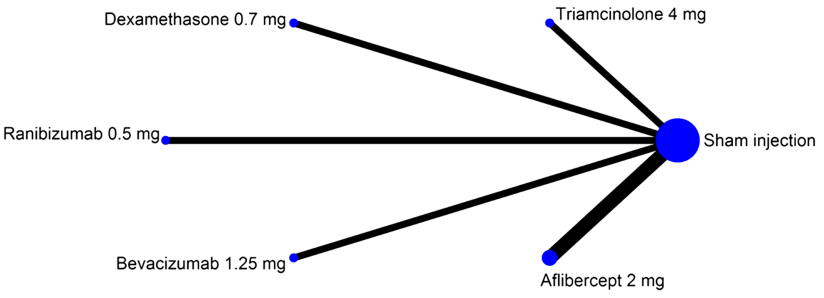

Figure 2 Network of randomised controlled trials comparing different treatments for proportions of gaining three or more lines of vision.

letters gained and the mean change in BCVA. Dexamethasone was less effective compared with these drugs.

\section{Strengths and limitations}

This is the first study providing an indirect comparison of drugs to treat macular oedema secondary to CRVO. A robust search strategy, screening process and data extraction were used, and this analysis drew on a systematic review. The studies included had, in general, a low risk of bias. Safety was not considered in this study but is described in detail elsewhere. ${ }^{45}$ Five different drugs were suitable for NMA. Unpublished data were obtained from one author. ${ }^{42-44}$ Bayesian methods were used for the NMA. There was good model fit and convergence within the analysis.

However, pre-specified outcomes were not reported in all studies and the sample size varied considerably. For example, Epstein et al, ${ }^{42-44}$ assessing bevacizumab, only included 30 participants in each arm. This resulted in wide CrIs from the NMA, which could have led to a type 1 error, especially with regard to the proportions of patients losing $\geq 3$ lines. The SCORE study compared triamcinolone to observation. ${ }^{23-36}$ The NMA assumes $\mathrm{a}^{11}$ similar effect of sham and observation and this may result in a small degree of bias. Only 6 months of data were included, and the long-term effects are not known. Using a 6-month follow-up period may disadvantage dexamethasone because peak effect in the GENEVA trials was seen at 90 days, and by 6 months, benefits had been largely lost. ${ }^{6-8}$

As with most network meta-analyses, methodological heterogeneity was present. There were some differences among the trials. For example, CRUISE, ${ }^{9}{ }^{10}$ assessing ranibizumab, did not include as many patients with ischaemic CRVO as the aflibercept trials. ${ }^{12} 13$ There were also some small differences in the chronicity of macular oedema and the mean BCVA at baseline.

Meaning of the study: possible explanations and implications for clinicians and policymakers

No head-to-head trials comparing aflibercept, bevacizumab, ranibizumab, triamcinolone and dexamethasone have been published in CRVO. Part of the reason for this is that the Food and Drug Administration requires proof of the safety and effectiveness of a drug. ${ }^{46}$ The easiest and quickest method for pharmaceutical companies to produce this proof is through placebo controlled trials. Trials comparing new medications to current best treatment would be considerably more useful to clinicians and patients.

Head-to-head trials comparing some of these drugs are available in other conditions. For example, a comparison of ranibizumab and bevacizumab was undertaken in age-related macular degeneration in the Comparison of Age-related macular degeneration Treatment Trials (CATT) ${ }^{47}$ and alternative treatments to Inhibit VEGF in patients with Age-related choroidal Neovascularisation (IVAN) ${ }^{48}$ trials. Both of these trials found no difference in effectiveness between ranibizumab and bevacizumab. Furthermore, an indirect comparison of ranibizumab and bevacizumab found no evidence of a difference between these drugs. ${ }^{49}$ Thus, it is highly probable that this may also apply in CRVO. The difference seen in our results regarding bevacizumab may be due to the low number of patients included in Epstein et $a l^{42-44}$ In the CATT trial, more patients were hospitalised in the bevacizumab arm, but the authors did not believe that this was explained by a direct effect of bevacizumab. ${ }^{47}$ The 2-year results from the IVAN showed little difference in cardiovascular events, with the number being insignificantly lower with bevacizumab. ${ }^{50}$ Ranibizumab and aflibercept were directly compared in two similarly designed trials, VEGF Trap-eye: investigation of Efficacy and safety in Wet age-related macular degeneration (VIEW 1 and 2). ${ }^{51}$ Similar efficacy and safety was found in both drugs.

From the included trials it is clear that intraocular steroids are associated with complications, including increased intraocular pressure and cataract formation. $.^{6-8} 23-36$ These are substantial drawbacks for using steroids to treat macular oedema in CRVO. However, many affected patients may already be pseudophakic and, on these, the use of intraocular steroids may be reasonable. Steroids may have a place in the treatment pathway of patients who have failed on anti-VEGF therapy, but this is yet to be tested. The anti-VEFG drugs have a good safety profile and do not cause cataract formation. ${ }^{9-13}{ }^{42-44}$ For this reason they are more likely to be favoured by clinicians than steroids.

Aflibercept, compared with ranibizumab and bevacizumab, targets a wider range of cytokines and may have a stronger binding affinity. ${ }^{52}$ Initial results suggested that aflibercept would require fewer injections than ranibizumab. ${ }^{51}$ Heier and colleagues compared aflibercept and ranibizumab in two similarly designed randomised controlled trials in age-related macular degeneration. They found that $2 \mathrm{mg}$ aflibercept administered every 8 weeks produced similar effects at 96 weeks to $0.5 \mathrm{mg}$ ranibizumab administered every 4 weeks. ${ }^{51}$ This was reflected in the FDA Dermatologic and Ophthalmic Drugs Advisory Committee recommendation that aflibercept should be given every 
Table 3 Risk of bias

\begin{tabular}{|c|c|c|c|c|c|c|c|}
\hline $\begin{array}{l}\text { Study } \\
\text { (author and } \\
\text { year) }\end{array}$ & $\begin{array}{l}\text { Adequate } \\
\text { sequence } \\
\text { generation }\end{array}$ & $\begin{array}{l}\text { Allocation } \\
\text { concealment }\end{array}$ & Masking & $\begin{array}{l}\text { Incomplete } \\
\text { outcome data } \\
\text { addressed }\end{array}$ & $\begin{array}{l}\text { Free of } \\
\text { selective } \\
\text { reporting }\end{array}$ & $\begin{array}{l}\text { Free of other bias (eg, } \\
\text { similarity at baseline, } \\
\text { power assessment) }\end{array}$ & Funder \\
\hline $\begin{array}{l}\text { Geneva } \\
2010^{6-8}\end{array}$ & Low & Low & $\begin{array}{l}\text { Partial: patients and } \\
\text { assessors of efficacy } \\
\text { variables }\end{array}$ & $\begin{array}{l}\text { Low: ITT analysis, } \\
94 \% \text { FU at } 6 \text { months }\end{array}$ & Low & $\begin{array}{l}\text { Power: } 81 \% \text { power to } \\
\text { detect difference in } \\
\text { primary outcome with } \\
\mathrm{n}=495 \text { for each trial } \\
\text { Similarity at baseline: yes }\end{array}$ & Allergan Inc \\
\hline $\begin{array}{l}\text { Score } \\
2009^{23-36}\end{array}$ & Low & Unclear & $\begin{array}{l}\text { Partial (physicians and } \\
\text { patients masked to dose } \\
\text { but not triamcinolone vs } \\
\text { observation) }\end{array}$ & $\begin{array}{l}\text { Low: ITT analysis, } \\
83-90 \% \text { FU at } \\
12 \text { months }\end{array}$ & Low & $\begin{array}{l}\text { Power: } 80 \% \text { power to } \\
\text { detect difference in } \\
\text { primary outcome with } \\
\mathrm{n}=486 \text { (but only } 271 \\
\text { randomised) } \\
\text { Similarity at baseline: yes }\end{array}$ & $\begin{array}{l}\text { National Eye Institute } \\
\text { grants, Allergan }\end{array}$ \\
\hline $\begin{array}{l}\text { Copernicus } \\
2012^{1213}\end{array}$ & Low & Unclear & Low: double-blind & $\begin{array}{l}\text { Low: ITT analysis, } \\
89.9 \% \text { assessed at } \\
\text { primary end point }\end{array}$ & Low & $\begin{array}{l}\text { Power: } 90 \% \text { power to } \\
\text { detect difference in } \\
\text { primary outcome with } \\
\mathrm{n}=165 \\
\text { Similarity at baseline: yes }\end{array}$ & $\begin{array}{l}\text { Bayer HealthCare, } \\
\text { Regeneron } \\
\text { Pharmaceuticals }\end{array}$ \\
\hline $\begin{array}{l}\text { Galileo } \\
2012^{11}\end{array}$ & Unclear & Unclear & Low: double-blind & $\begin{array}{l}\text { Low: ITT analysis, } \\
86 \% \text { assessed at } \\
\text { primary end point }\end{array}$ & Low & $\begin{array}{l}\text { Power: } 90 \% \text { power to } \\
\text { detect difference in } \\
\text { primary outcome with } \\
\mathrm{n}=150 \\
\text { Similarity at baseline: yes }\end{array}$ & $\begin{array}{l}\text { Bayer HealthCare, } \\
\text { Regeneron } \\
\text { Pharmaceuticals }\end{array}$ \\
\hline $\begin{array}{l}\text { Cruise } \\
2010^{910}\end{array}$ & Low & Unclear & $\begin{array}{l}\text { Low: patients and } \\
\text { evaluating examiners, } \\
\text { injecting physicians } \\
\text { masked to dose }\end{array}$ & $\begin{array}{l}\text { Low: ITT analysis, } \\
88.5-97.7 \% \\
\text { completed } 6 \text { months }\end{array}$ & Low & $\begin{array}{l}\text { Power: not reported } \\
\text { Similarity at baseline: yes }\end{array}$ & Genentech Inc. \\
\hline $\begin{array}{l}\text { Epstein } \\
2012^{42-44}\end{array}$ & Unclear & Low & $\begin{array}{l}\text { Low: patients, outcome } \\
\text { assessors }\end{array}$ & $\begin{array}{l}\text { Low: ITT analysis; } \\
\text { missing data for } 2 \\
\text { patients (primary } \\
\text { endpoint) }\end{array}$ & Low & $\begin{array}{l}\text { Power: } 80 \% \text { power to } \\
\text { detect difference in } \\
\text { primary outcome with } \\
\mathrm{n}=24 \text { per group } \\
\text { Similarity at baseline: yes }\end{array}$ & $\begin{array}{l}\text { Unclear; authors are } \\
\text { consultants for Allergan, } \\
\text { Novartis, Alcon, Bayer }\end{array}$ \\
\hline
\end{tabular}




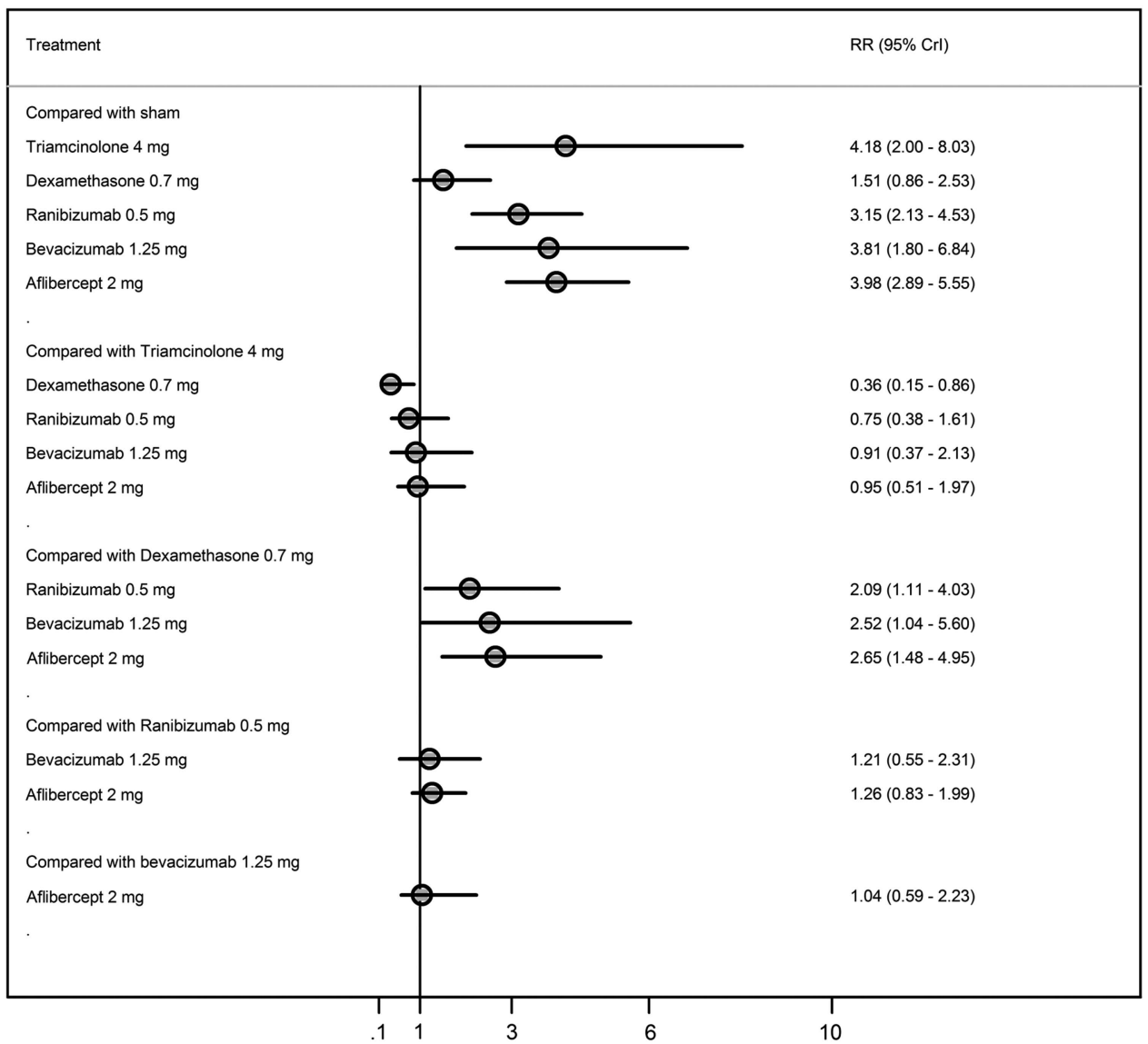

Figure 3 Proportions of patients gaining three lines or more from baseline to 6 months.

2 months following three initial monthly doses in age-related macular oedema. ${ }^{53}$ This may be because aflibercept also appears to last longer in the eye than ranibizumab. ${ }^{54}$ Age-related macular degeneration is a more aggressive condition than CRVO and so it is unlikely that more frequent dosing would be needed. Therefore, aflibercept may be preferred because it would reduce pressure on outpatient clinics.
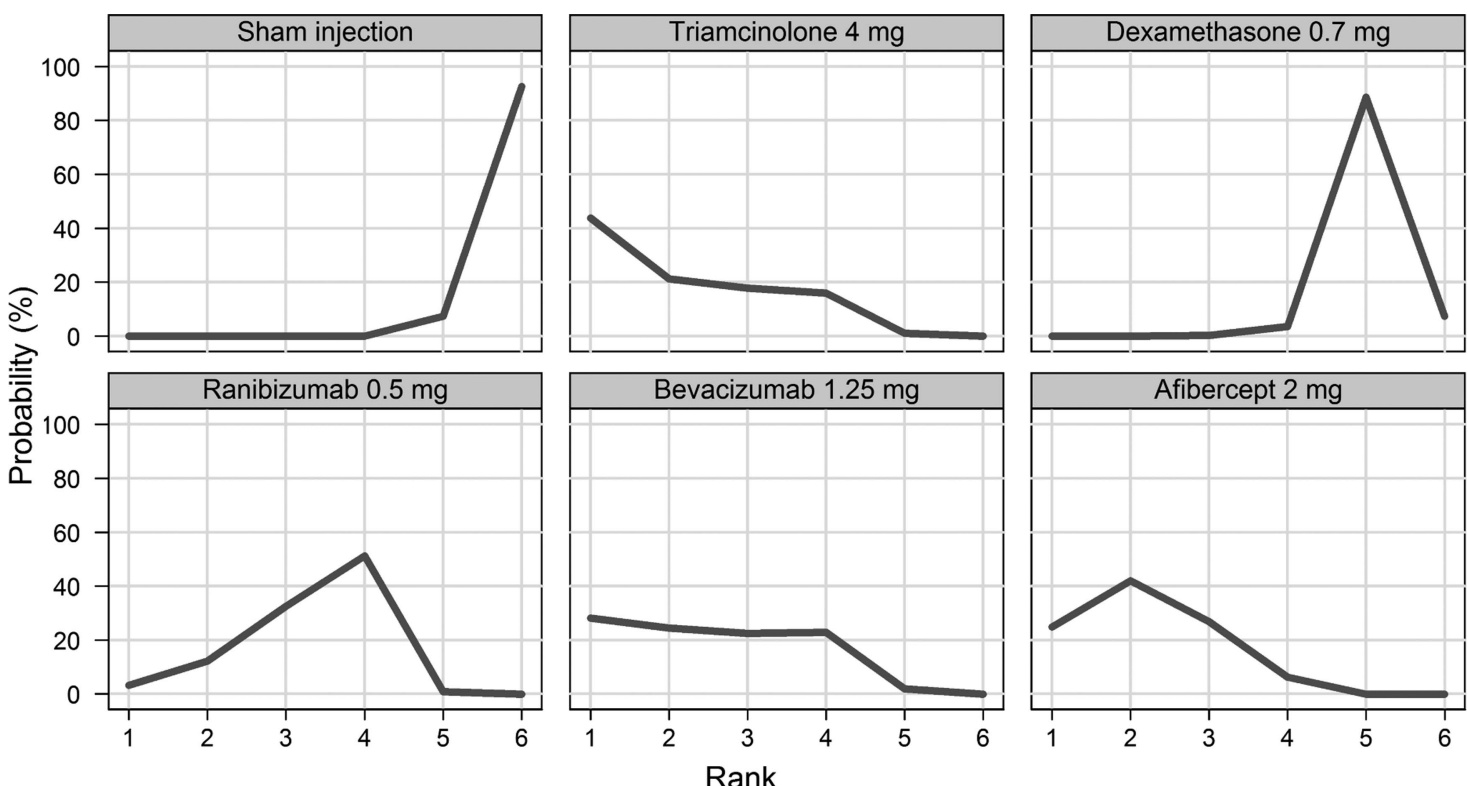

Figure 4 Rankogram for gaining $\geq 3$ lines-distribution of the probabilities of every treatment being ranked at each of the possible six positions. 


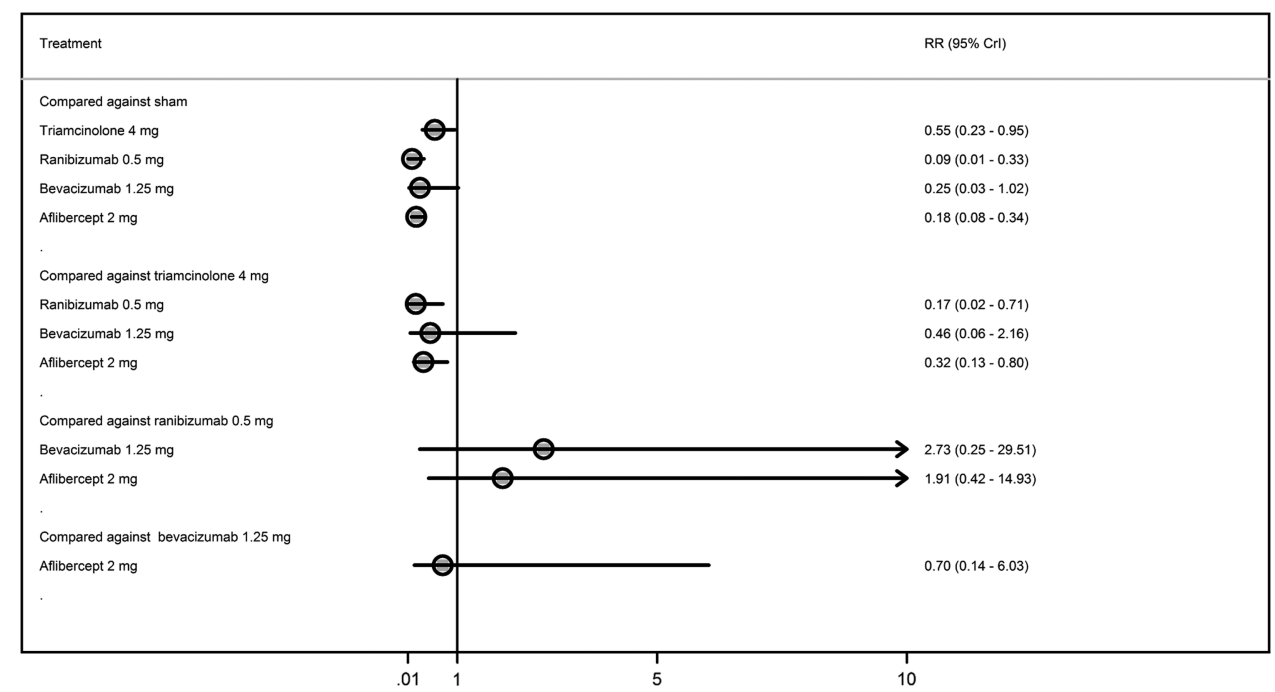

Figure 5 Proportions of patients losing three lines or more from baseline to 6 months.

Furthermore, there is some evidence from patients with age-related macular degeneration that aflibercept may be effective in patients who have not responded to ranibizumab. ${ }^{55} 56$ This may be due to the higher affinity and wider number of cytokines that are targeted. There is no reason to suspect that these effects are any different for the macular oedema caused by CRVO. However, we have as yet no evidence as to whether ranibizumab would be effective after aflibercept has failed.

The National Institute of Health and Care Excellence has recommended dexamethasone, ranibizumab and aflibercept as options in the treatment of macular oedema secondary to CRVO. ${ }^{18-20}$ Until these technologies are reviewed together and compared with each other, clinicians are left with three recommended drugs. It should be noted that during the appraisal of ranibizumab the evidence review group found that in the costeffectiveness analysis dexamethasone was extendedly dominated by ranibizumab (an intervention is judged not be cost-effective because it has an ICER that is greater than that of a more effective intervention). The committee appraising ranibizumab did not re-consider the previous appraisal decision on dexamethasone.

Our results show that dexamethasone was not as effective as ranibizumab or aflibercept, at 6 months follow-up and with the dosing regimens in the trials. However, these results do not assess quality of life or cost effectiveness. Bevacizumab is likely to prove more cost effective than both aflibercept and ranibizumab because
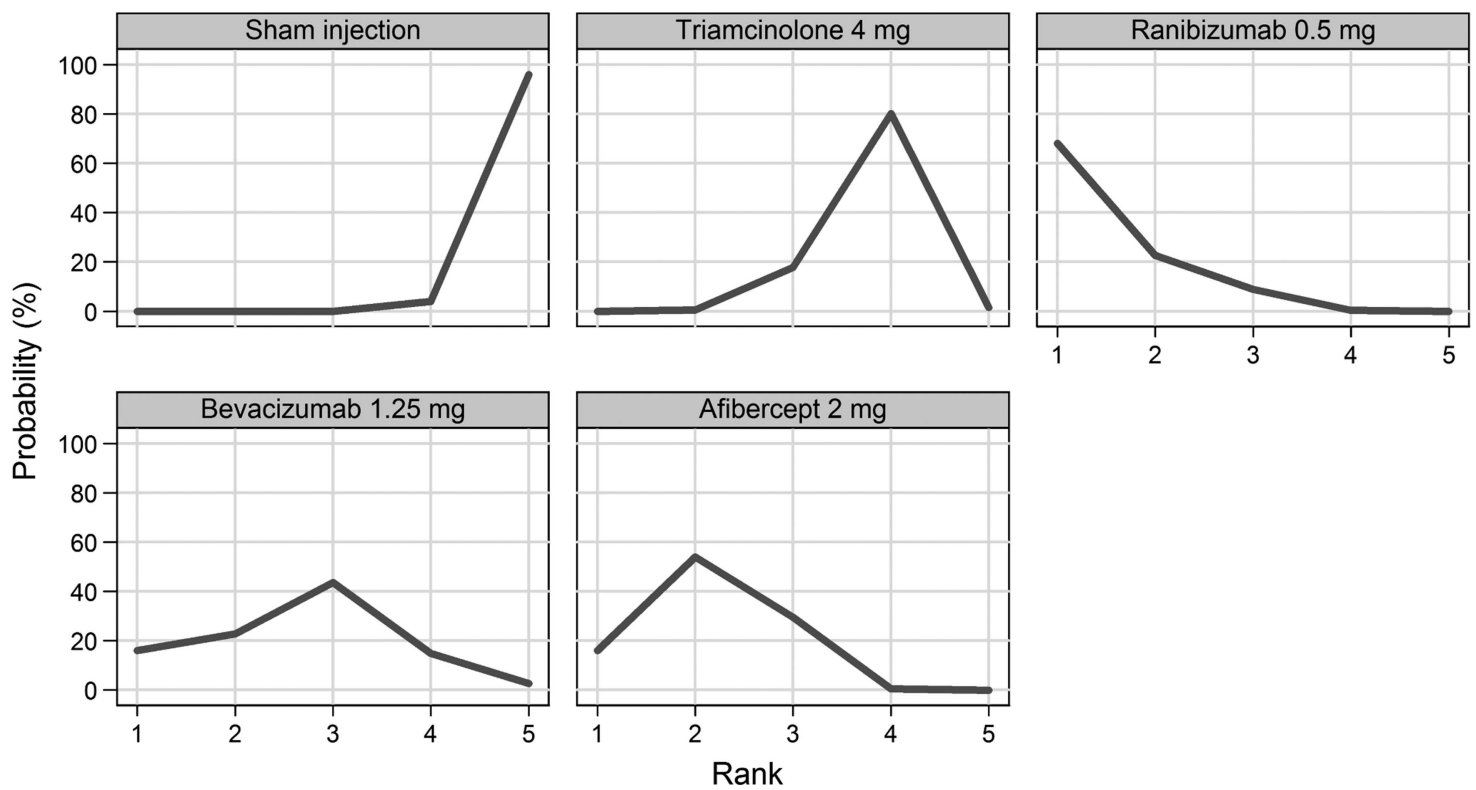

Figure 6 Rankogram for losing $\geq 3$ lines-distribution of the probabilities of every treatment being ranked at each of the possible six positions. 


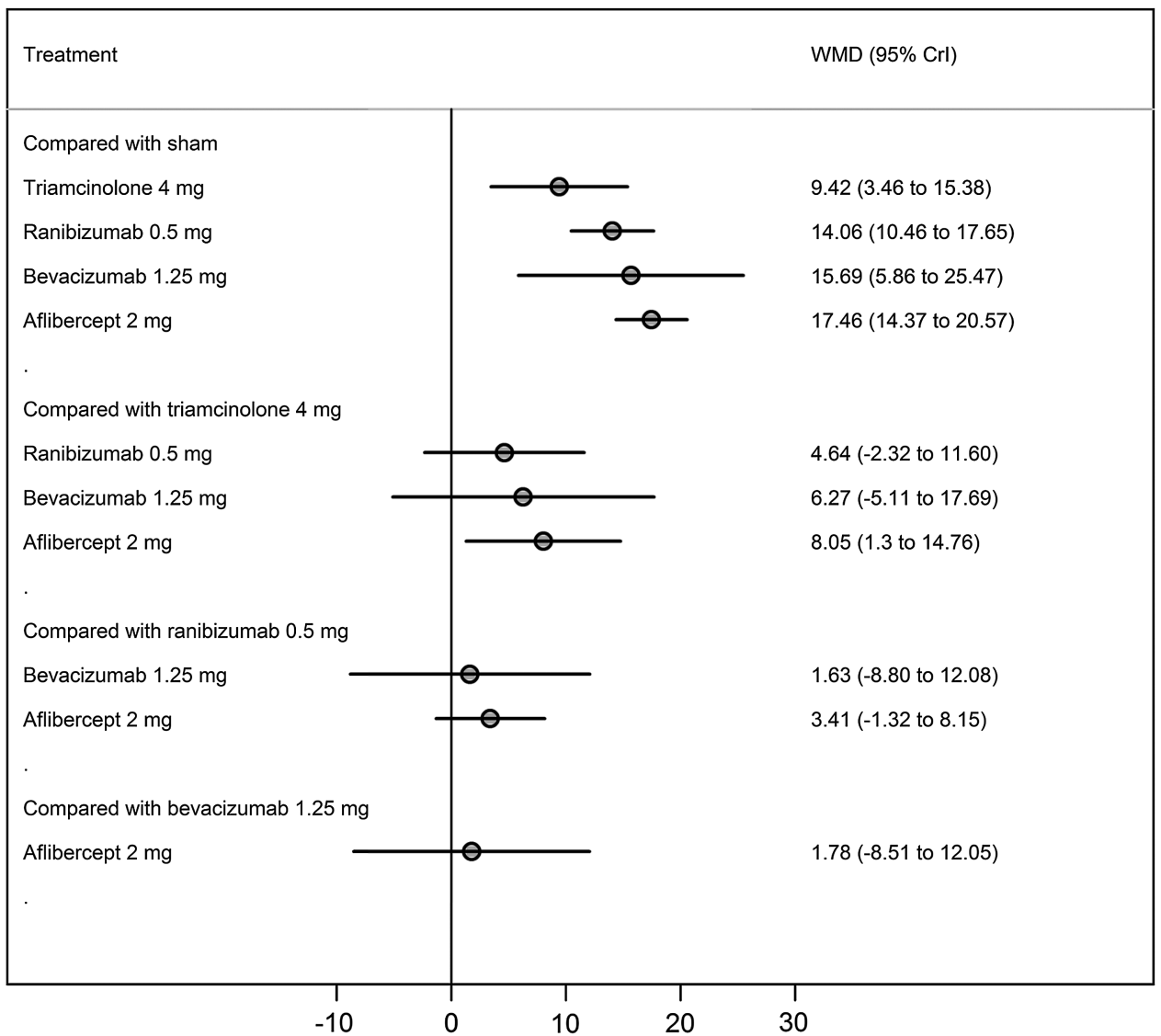

Figure 7 Mean best corrected visual acuity change from baseline to 6 months.

it is substantially less expensive. ${ }^{57}$ However, the National Institute for Health and Care Excellence has not issued guidance on bevacizumab because it does not have a license for use in the eye.

\section{Unanswered questions and future research}

Not all patients benefit from the use of anti-VEGF drugs; only about $60 \%$ gain 15 or more letters. It is not clear why some patients benefit more than others. Future
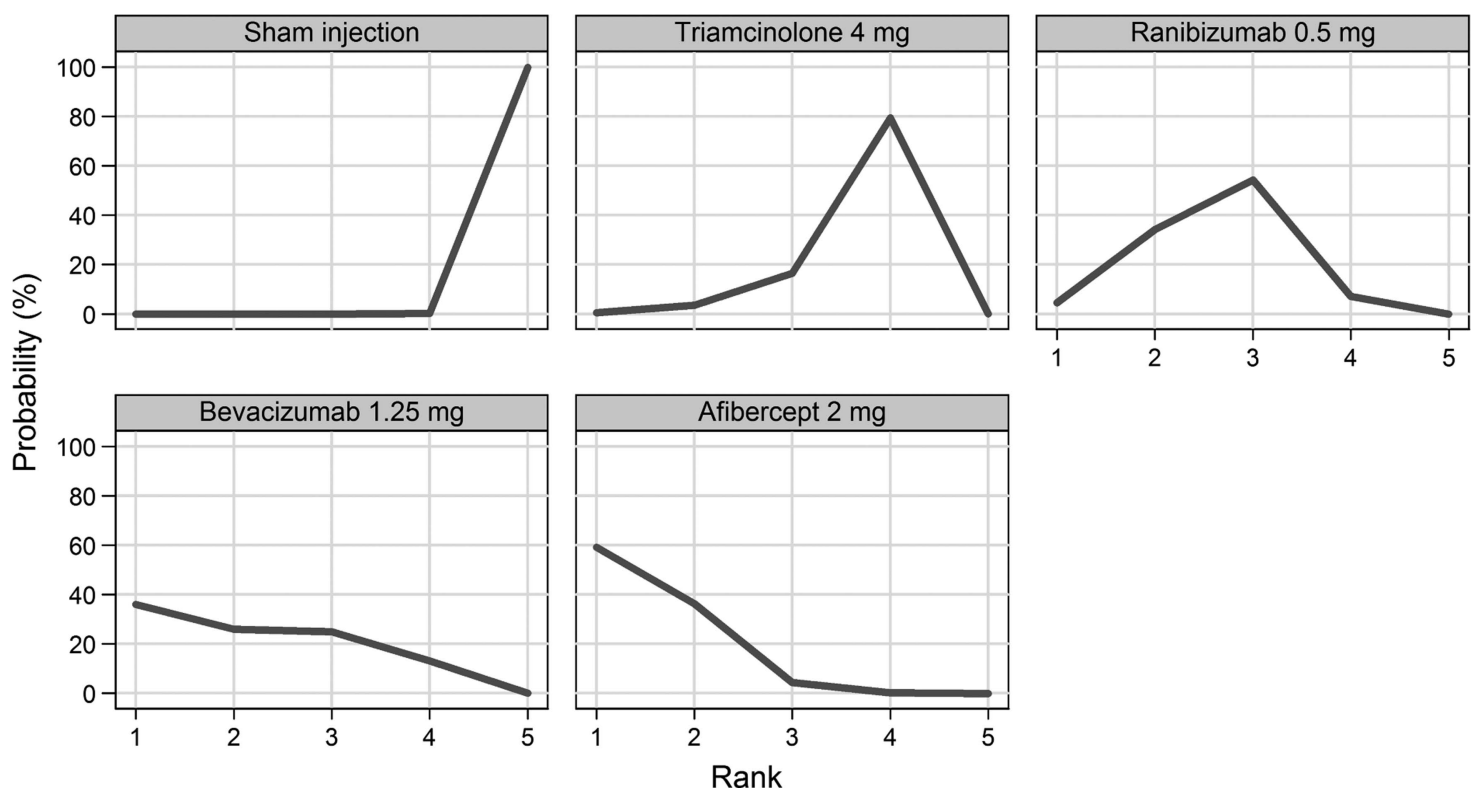

Figure 8 Rankogram for mean change in best corrected visual acuity-distribution of the probabilities of every treatment being ranked at each of the possible six positions. 
research should focus on identifying subgroups of patients who are likely to benefit. Only a few of the trials included ischaemic patients, and in those trials only a few patients with ischaemia were included. ${ }^{11-13}$ More research assessing the effectiveness of these drugs in severely ischaemic patients is needed.

Head-to-head trials comparing ranibizumab, aflibercept, bevacizumab and triamcinolone are needed. These should include assessment of cost effectiveness. To assist this, a better measure of quality of life is needed for patients with eye conditions. The widely used EQ5D may not be sensitive enough to measure changes that are important to patients, such as the ability to drive.

In conclusion, we have found no evidence of differences between ranibizumab, bevacizumab, aflibercept and triamcinolone for improving vision. The anti-VEGFs are likely to be favoured because they are not associated with steroid-induced cataract formation. Clinicians may prefer Aflibercept because it might require fewer injections.

Acknowledgements The authors thank Christine Clar, Sian Thomas and Rachel Court for assisting with searches, screening and data extraction for the systematic review that precedes this study. They also thank the authors of the Epstein 2012 trial for providing addition data.

Contributors NW conceived the idea. All authors contributed to the design of the study. DS and OAU undertook the statistical analysis. JAF, DS and OAU wrote the first draft of the manuscript. All authors redrafted and agreed on the final article. JAF is the guarantor.

Funding This research received no specific grant from any funding agency in the public, commercial or not-for-profit sectors.

Competing interests None.

Provenance and peer review Not commissioned; externally peer reviewed.

Data sharing statement No additional data are available.

Open Access This is an Open Access article distributed in accordance with the Creative Commons Attribution Non Commercial (CC BY-NC 4.0) license, which permits others to distribute, remix, adapt, build upon this work noncommercially, and license their derivative works on different terms, provided the original work is properly cited and the use is non-commercial. See: http:// creativecommons.org/licenses/by-nc/4.0/

\section{REFERENCES}

1. Deramo VA, Cox TA, Syed AB, et al. Vision-related quality of life in people with central retinal vein occlusion using the 25-item National Eye Institute Visual Function Questionnaire. Arch Ophthalmol 2003;121:1297-302.

2. Klein R, Moss SE, Meuer SM, et al. The 15-year cumulative incidence of retinal vein occlusion: the Beaver Dam Eye Study. Arch Ophthalmol 2008;126:513-18.

3. Hayreh SS, Podhajsky PA, Zimmerman MB. Natural history of visual outcome in central retinal vein occlusion. Ophthalmology 2011;118:119-33.

4. McIntosh RL, Rogers SL, Lim L, et al. Natural history of central retinal vein occlusion: an evidence-based systematic review. Ophthalmology 2010;117:1113-23.

5. The Royal College of Ophthalmologists. Interim Guidelines for Management of Retinal Vein Occlusion. Secondary Interim Guidelines for Management of Retinal Vein Occlusion. 2010. http:// www.rcophth.ac.uk/core/core_picker/download.asp?id $=728 \&$ filetitle=Interim+Guidelines+for+Management+of+Retinal+Vein+ Occlusion+2010

6. Haller JA, Bandello F, Belfort R Jr, et al. Randomized, sham-controlled trial of dexamethasone intravitreal implant in patients with macular edema due to retinal vein occlusion. Ophthalmology 2010;117:1134-46.
7. Haller JA, Bandello F, Belfort R Jr, et al. Dexamethasone intravitreal implant in patients with macular edema related to branch or central retinal vein occlusion twelve-month study results. Ophthalmology 2011:118:2453-60.

8. Yeh WS, Haller JA, Lanzetta P, et al. Effect of the duration of macular edema on clinical outcomes in retinal vein occlusion treated with dexamethasone intravitreal implant. Ophthalmology 2012;119:1190-8.

9. Brown DM, Campochiaro PA, Singh RP, et al. Ranibizumab for macular edema following central retinal vein occlusion: six-month primary end point results of a phase III study. Ophthalmology 2010;117:1124-33.

10. Campochiaro PA, Brown DM, Awh CC, et al. Sustained benefits from ranibizumab for macular edema following central retinal vein occlusion: twelve-month outcomes of a phase III study. Ophthalmology 2011;118:2041-9.

11. Holz FG, Roider J, Ogura Y, et al. VEGF Trap-Eye for macular oedema secondary to central retinal vein occlusion: 6-month results of the phase III GALILEO study. Br J Ophthalmol 2013;97:278-84.

12. Boyer D, Heier J, Brown DM, et al. Vascular endothelial growth factor Trap-Eye for macular edema secondary to central retinal vein occlusion: six-month results of the phase 3 COPERNICUS study. Ophthalmology 2012;119:1024-32.

13. Brown DM, Heier JS, Clark WL, et al. Intravitreal aflibercept injection for macular edema secondary to central retinal vein occlusion: 1 -year results from the phase 3 COPERNICUS study. Am J Ophthalmol 2013;155:429-37.

14. Michels S, Rosenfeld PJ, Puliafito CA, et al. Systemic bevacizumab (Avastin) therapy for neovascular age-related macular degeneration twelve-week results of an uncontrolled open-label clinical study. Ophthalmology 2005;112:1035-47.

15. Arevalo JF, Fromow-Guerra J, Quiroz-Mercado H, et al. Primary intravitreal bevacizumab (Avastin) for diabetic macular edema: results from the Pan-American Collaborative Retina Study Group at 6-month follow-up. Ophthalmology 2007;114:743-50.

16. Rabena MD, Pieramici DJ, Castellarin AA, et al. Intravitreal bevacizumab (Avastin) in the treatment of macular edema secondary to branch retinal vein occlusion. Retina 2007;27:419-25.

17. Algvere PV, Epstein D, von Wendt G, et al. Intravitreal bevacizumab in central retinal vein occlusion: 18-month results of a prospective clinical trial. Eur J Ophthalmol 2011;21:789-95.

18. National Institute for Health and Care Excellence. Ranibizumab for treating visual impairment caused by macular oedema secondary to retinal vein occlusion: NICE technology appraisal guidance 283 . 2013. http://guidance.nice.org.uk/TA283/Guidance/pdf/English

19. National Institute for Health and Clinical Excellence. Dexamethasone intravitreal implant for the treatment of macular oedema secondary to retinal vein occlusion: NICE technology appraisal guidance 229. 2011. http://guidance.nice.org.uk/TA229/ Guidance/pdf/English

20. National Institute for Health and Care Excellence. Aflibercept for treating visual impairment caused by macular oedema secondary to central retinal vein occlusion. NICE technology appraisal guidance 305. 2014. http://guidance.nice.org.uk/TA305

21. Higgins JP, Altman DG, Gotzsche PC, et al. The Cochrane Collaboration's tool for assessing risk of bias in randomised trials. BMJ 2011;343:d5928.

22. Hozo S, Djulbegovic B, Hozo I. Estimating the mean and variance from the median, range, and the size of a sample. BMC Med Res Methodol 2005:5:13.

23. Bhavsar AR, Ip MS, Glassman AR, et al. The risk of endophthalmitis following intravitreal triamcinolone injection in the DRCRnet and SCORE clinical trials. Am J Ophthalmol 2007;144:454-6.

24. Blodi BA, Domalpally A, Scott IU, et al. Standard Care vs Corticosteroid for Retinal Vein Occlusion (SCORE) Study system for evaluation of stereoscopic color fundus photographs and fluorescein angiograms: SCORE Study Report 9. Arch Ophthalmol 2010;128:1140-5.

25. Chan CK, Ip MS, VanVeldhuisen PC, et al. SCORE Study report \#11: incidences of neovascular events in eyes with retinal vein occlusion. Ophthalmology 2011;118:1364-72.

26. Ip M, Oden N, VanVeldhuisen $\mathrm{P}$, et al. The standard care vs. corticosteroid for retinal vein occlusion study: design and baseline characteristics. Am Acad Ophthalmol 2008;260.

27. Ip MS, Oden NL, Scott IU, et al. SCORE Study report 3: study design and baseline characteristics. Ophthalmology 2009;116:1770-7.

28. Ip MS, Scott IU, VanVeldhuisen PC, et al. A randomized trial comparing the efficacy and safety of intravitreal triamcinolone with observation to treat vision loss associated with macular edema secondary to central retinal vein occlusion: the Standard Care vs 
Corticosteroid for Retinal Vein Occlusion (SCORE) study report 5. Arch Ophthalmol 2009;127:1101-14.

29. Myers D, Blodi B, Ip M, et al. Reading center evaluation of OCT images from patients enrolled in the standard care vs. Corticosteroid for Retinal Vein Occlusion (SCORE) Study. IOVS 2006;47:ARVO E-abstract 5194.

30. Oden NL, Veldhuisen PC, Scott IU, et al. Temporal variability of OCT in retinal vein occlusion participants in the SCORE study. IOVS 2007;48:ARVO E-abstract 107.

31. Scott IU, Blodi BA, Ip MS, et al. SCORE study report 2: Interobserver agreement between investigator and reading center classification of retinal vein occlusion type. Ophthalmology 2009;116:756-61.

32. Scott IU, Oden NL, VanVeldhuisen PC, et al. SCORE Study Report 7: incidence of intravitreal silicone oil droplets associated with staked-on vs luer cone syringe design. Am J Ophthalmol 2009;148:725-32.

33. Scott IU, VanVeldhuisen PC, Oden NL, et al. Baseline predictors of visual acuity and retinal thickness outcomes in patients with retinal vein occlusion: Standard Care Versus COrticosteroid for REtinal Vein Occlusion Study report 10. Ophthalmology 2011;118:345-52.

34. Scott IU, VanVeldhuisen PC, Oden NL, et al. SCORE Study report 1: baseline associations between central retinal thickness and visual acuity in patients with retinal vein occlusion. Ophthalmology 2009;116:504-12.

35. Scott IU, VanVeldhuisen PC, Oden NL, et al. Baseline characteristics and response to treatment of participants with hemiretinal compared with branch retinal or central retinal vein occlusion in the standard care vs COrticosteroid for REtinal vein occlusion (SCORE) study: SCORE study report 14. Arch Ophthalmol 2012;130:1517-24.

36. Warren K, Blodi BA, Oden N, et al. Reading center evaluation of baseline retinal images in the standard care vs. Corticosteroid for Retinal Vein Occlusion (SCORE) Study. IOVS 2008;ARVO E-abstract 2136.

37. Caldwell DM, Ades AE, Higgins JP. Simultaneous comparison of multiple treatments: combining direct and indirect evidence. $B M J$ 2005;331:897-900.

38. Lu G, Ades AE. Combination of direct and indirect evidence in mixed treatment comparisons. Stat Med 2004;23:3105-24.

39. Spiegelhalter D, Thomas A, Best N, et al. WinBUGS User Manual: Version 1.4. Cambridge, MA: MRC Biostatistics Unit, 2003.

40. Brooks SP, Gelman A. General methods for monitoring convergence of iterative simulations. J Comput Graph Stat 1998;7:434-55.

41. Salanti G, Ades AE, loannidis JP. Graphical methods and numerical summaries for presenting results from multiple-treatment metaanalysis: an overview and tutorial. J Clin Epidemiol 2011;64:163-71.

42. Epstein D, Algvere P, Von WG, et al. Long-term benefit from bevacizumab for macular edema in central retinal vein occlusion: 12-month results of a prospective study. Acta Ophthalmol 2012;90:48

43. Epstein DL, Algvere PV, Von WG, et al. Benefit from bevacizumab for macular edema in central retinal vein occlusion: twelve-month results of a prospective, randomized study. Ophthalmology 2012;119:2587-91.

44. Epstein DL, Algvere PV, Von WG, et al. Bevacizumab for macular edema in central retinal vein occlusion: a prospective, randomized, double-masked clinical study. Ophthalmology 2012;119:1184-9.

45. Ford JA, Clar C, Lois N, et al. Treatments for macular oedema following central retinal vein occlusion: systematic review. BMJ Open 2014;4:e004120.

46. FDA. Drug Study Designs-Information Sheet. Guidance for Institutional Review Boards and Clinical Investigators. Secondary Drug Study Designs_-Information Sheet. Guidance for Institutional Review Boards and Clinical Investigators. 2011. http://www.fda.gov/ RegulatoryInformation/Guidances/ucm126501.htm

47. Martin DF, Maguire MG, Fine SL, et al. Ranibizumab and bevacizumab for treatment of neovascular age-related macular degeneration: two-year results. Ophthalmology 2012;119:1388-98.

48. Chakravarthy U, Harding SP, Rogers CA, et al. Ranibizumab versus bevacizumab to treat neovascular age-related macular degeneration: one-year findings from the IVAN randomized trial. Ophthalmology 2012;119:1399-411.

49. Ford JA, Elders A, Shyangdan D, et al. The relative clinical effectiveness of ranibizumab and bevacizumab in diabetic macular oedema: an indirect comparison in a systematic review. BMJ 2012;345:e5182.

50. Chakravarthy U, Harding SP, Rogers CA, et al. Alternative treatments to inhibit VEGF in age-related choroidal neovascularisation: 2-year findings of the IVAN randomised controlled trial. Lancet 2013;382:1258-67.

51. Heier JS, Brown DM, Chong V, et al. Intravitreal aflibercept (VEGF trap-eye) in wet age-related macular degeneration. Ophthalmology 2012;119:2537-48.

52. Papadopoulos N, Martin J, Ruan Q, et al. Binding and neutralization of vascular endothelial growth factor (VEGF) and related ligands by VEGF Trap, ranibizumab and bevacizumab. Angiogenesis 2012;15:171-85.

53. FDA. VEGF TRAP-EYE (aflibercept ophthalmic solution) Ophthalmologic Drugs Advisory Committee. Secondary VEGF TRAP-EYE (aflibercept ophthalmic solution). Ophthalmologic Drugs Advisory Committee. 2011. http://www.fda.gov/downloads/ AdvisoryCommittees/CommitteesMeetingMaterials/Drugs/ DermatologicandOphthalmicDrugsAdvisoryCommittee/ UCM259143.pdf

54. Stewart MW, Rosenfeld PJ. Predicted biological activity of intravitreal VEGF Trap. Br J Ophthalmol 2008:92:667-8.

55. Bakall B, Folk JC, Boldt HC, et al. Aflibercept therapy for exudative age-related macular degeneration resistant to bevacizumab and ranibizumab. Am J Ophthalmol 2013;156:15-22.e1.

56. Cho H, Shah CP, Weber M, et al. Aflibercept for exudative AMD with persistent fluid on ranibizumab and/or bevacizumab. $\mathrm{Br} J$ Ophthalmol 2013;97:1032-5.

57. Raftery J, Clegg A, Jones J, et al. Ranibizumab (Lucentis) versus bevacizumab (Avastin): modelling cost effectiveness. $\mathrm{Br} J$ Ophthalmol 2007;91:1244-6. 